\title{
Students' Opinions on the Use of Computer Rooms for Teaching Anatomy
}

\author{
La Opinión de los Alumnos Sobre la Utilización de Salas de Informática \\ para la Enseñanza de la Anatomía
}

Etenildo Dantas Cabral \& Joanna Martins Novais Barbosa

CABRAL, D. E. \& BARBOSA, N. J. M. Students' opinions on the use of computer rooms for teaching Anatomy. Int. J. Morphol., 23(3):267-270, 2005.

SUMMARY: The present study aimed to survey students' opinions on the use of computer-aided classes for teaching anatomy. Thus, a questionnaire with closed questions was administered at the end of the Anatomy course to undergraduate dental students, which produced a total of 76 valid questionnaires. While studying this subject, the students accessed a room equipped with computers containing previously installed Anatomy programs. The analysis of the questionnaires showed that for most students the computer room considerably facilitates the study of Anatomy and potentially increases the comprehension of the lessons' goals, as well as being an extremely important aid in studying anatomy. However, most students reported that they did not prefer this learning tool to the study of dissected cadavers, and considered that the computer room cannot replace cadavers. The present study concludes that the students interviewed consider the use of computer rooms as an effective adjunct to enhance the learning of anatomical concepts; nevertheless, it is a supplement to, not a surrogate for cadavers.

KEY WORDS: Anatomy; Education; Educational technology; Teaching Methods.

\section{INTRODUCTION}

The use of cadavers has been traditionally the chief pillar for learning Anatomy and many virtues have been ascribed to it (Azis et al., 2002), in addition to the process of dissecting a cadaver as a teaching method (Jones, 1997; Ellis, 2001). However, the limited availability of cadavers, the difficulties imposed by the ethical issues surrounding their use, among other arguments (McLaghlan et al., 2004), have led to the use of a variety of supplementary aids and substitutes, such as anatomical models in plastic matter like PVC (polyvinyl chloride). More recently, hardware and specialized software have been used to help students learn the three-dimensional spatial relationships of anatomical structures (Hariri et al., 2004). As Anatomy learning strongly depends on images, this subject is particularly amenable to the use of computer science.

In general, computers have benefited higher education, especially a number of health care specialties (Waugh et al. 1995; Kallinowski et al., 1997). They can, via Internet, aid interdisciplinary learning (Filler et al., 2000), and make lectures more interesting for students by means of multimedia presentations (Cassady, 1998; Perry \& Perry, 1998). Research on the efficacy of computer-based learning suggests that it can enhance students' performance in examinations (Kulik et al. 1983) reduce the time students need to spend studying (Kulik et al. 1986), as well as improving the way students process information (Najjar, 1996).

However, several aspects of the educational role of these new technologies still need further investigation, such as students' perceptions of their use, for instance in relation to the teaching of Anatomy. The aim of the present study is therefore to evaluate students' opinions on the use of computer rooms for teaching Anatomy.

\section{MATERIAL AND METHOD}

Type and place of study. This is a quantitative, investigatory study, carried out in the Department of Anatomy of the Universidade Federal de Pernambuco (UFPE), in Recife, Pernambuco, Brazil. 
Study population. The present study concerns students who took the compulsory discipline of Anatomy as part of the Dentistry course of UFPE (“Anatomy-7”), during the year 2002. This subject focuses on anatomical structures of the head, and on average there are 50 students every semester.

Use of computer room. After the teacher had presented the content of the discipline in the conventional classroom, students had access to a room equipped with computers in which Anatomy programs had been previously installed. In the computer room, students were divided into pairs for each computer, and used the software Netter's Clinical Anatomy Atlas, which they were taught how to manipulate. Students studied the content of the class of the day, using the program with the aid of a previously prepared lesson guide sheet, assisted by the teacher and the teacher aides of the discipline. After the standard lecture and before the practical class with cadavers, the computer room was used in 8 out of the 16 lectures scheduled by the discipline to cover the subject matter.

Sample and data collection. All the students present at the last lecture of the Anatomy syllabus were requested to participate in the study by filling in a questionnaire. A total of 76 questionnaires were handed back and duly marked at the end of two semesters, 26 from male and 50 from female students. The questionnaire used to elicit students' perceptions of the use of computer room consisted of 5 multiple-choice questions: (1) Do you think that the computer room helps in the study of anatomical structures?; (2) Does it enhance understanding of the objectives of the class?; (3) Is it preferable to studying cadavers?; (4) Is it necessary for the study of Anatomy? and (5) Can it replace dissected cadavers in the teaching of Anatomy?. For each question, the student had to choose one of five possible answers: not at all, only a little, to a certain extent, very much, and completely.

Data analysis. Data were processed using the computer program SPSS Version 11.0 for the production of descriptive and analytic statistics. In the descriptive statistics the frequency of the replies was determined for each item of the questionnaire; in the analytic statistics it was verified whether there was significant difference in the replies according to the student's gender, using the MannWhitney Nonparameric statistical test, considering the choice of answers on an ordinal scale from 1 to 5 .

\section{RESULTS}

An analysis of the questionnaire analysis showed that for many students (45\%) the use of the computer room is very beneficial in the study of Anatomy (Figure 1-A), as well as greatly enhancing understanding of the objectives of the class (42\%) (Figure 1-B). Furthermore, most students considered this teaching resource to be of great importance for studying
Anatomy (58\%) (Figure 1-D). However, the majority of students $(36 \%)$ indicated that they did not prefer it to cadaveric material (Figure 1-C), although it is interesting to note that a considerable percentage of students showed a strong preference for this new learning tool (16\%). Moreover, the vast majority did not like the idea of replacing cadavers by a computer room (Figure $1-E)$, even though there was a significant difference in the replies according to gender $(\mathrm{p}=0.005)$, with fewer female students rejecting such a replacement. With the other items the responses showed no significant differences between the sexes $(\mathrm{p}>0.05)$.

\section{DISCUSSION}

In an overall analysis, the results of the present study showed that for the students, the computer room facilitates the study of anatomy as well as their understanding of the objectives of the class, which suggests that this method benefits students' learning. This finding is consistent with the results of earlier studies on the effectiveness of computer-based learning (Kulik et al. 1983, 1986; Najjar). In addition, students reported the need for a computer room in the study of anatomy, which indicates that this method plays an important role in the Anatomy learning process that surpasses its merely illustrative purpose. The fact that students considered the use of computer room a necessary resource in anatomy teaching, even though most of them did not state a preference of this tool over cadaveric material, suggests that this new method provides important elements in the learning process that are not obtainable by other means.

With regard to students' preferences, another consideration is the need for further investigation in order to better identify whether such preferences are influenced by their familiarity with computers or by their attitude to dealing with cadavers. A lack of experience with computers, for instance, might have reduced students' preference for the computer room, but it should be remembered that university students' computer experience has been increasing rapidly over the years (Van Braak, 2004).

From the results of the present study, it may be confidently inferred that students perceive the use of computer rooms, or computers in general, as a necessary instrument in facilitating the study of Anatomy, but as a supplement to cadavers rather than a substitute. This is at variance with certain arguments against the use of cadaveric material in Anatomy teaching (McLaghlan et al.), at least with regard to students's wishes, but it reinforces the argument for giving students the opportunity to use multiple resources, that is, books, atlases, cadaveric material, plastic models, computer systems, etc, thus favoring flexibility in the acquisition of knowledge, in other words, student's ability to apply the acquired knowledge in a variety of different contexts (Salomon \& Perkins, 1989; Bridges, 1993). 
Does it facilitate the study of anatomy?

A

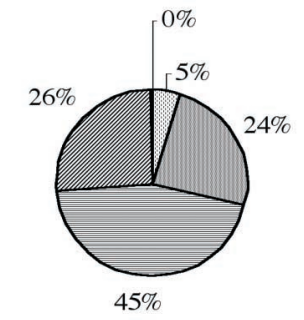

Is it preferable to studying cadavers?
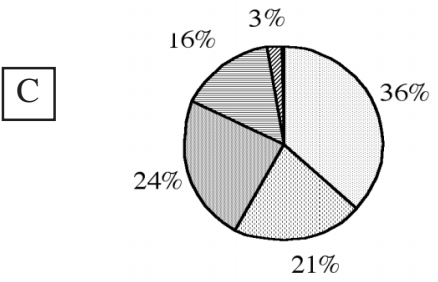

Does it enhance understanding of the objectives of the class?

\section{B}

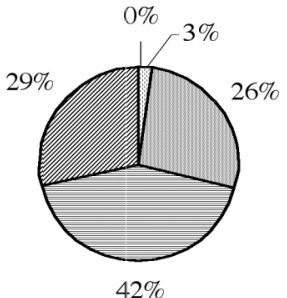

Is it necessary for the study of anatomy?
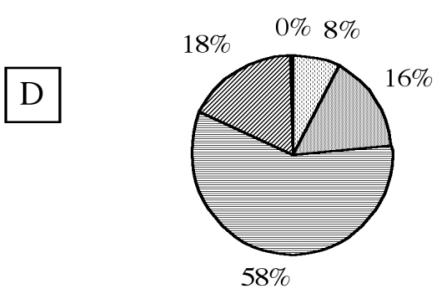

Can it replace dissected cadavers in the teaching of anatomy?

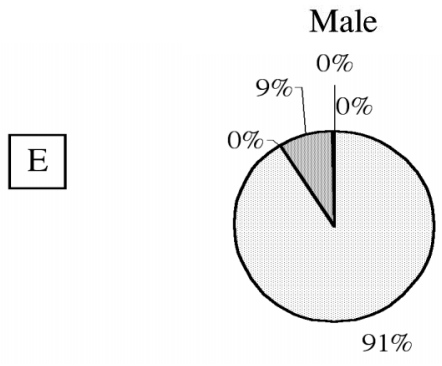

Female
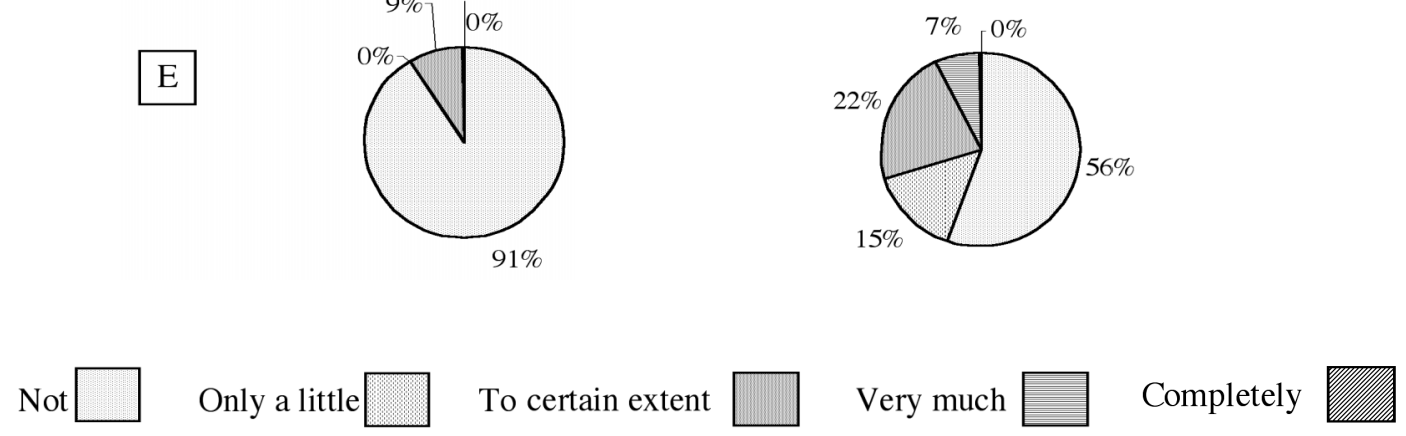

Fig. 1. Frequency of students' responses to the items of the questionnaire

The difference in the pattern of answers regarding the replacement of cadavers according to the student's gender may reflect gender differences in attitudes and computer use (Kirkpatrick \& Cuban, 1998; Whitley, 1997; Van Braak), but it may also reflect gender differences in attitudes to the handling of cadavers. Further investigation is necessary in order to clarify this issue.

In view of the fact that the interface provided by computer software influences the student's learning process and satisfaction (Evans et al., 2004), it is important to emphasize that the Anatomy software used by the students in this study was excessively simple, with images based on anatomical illustrations and very few interactive tools. It may be that the use of better quality programs with more instruments for the manipulation of images, like other software already available, will increase students' preference for the use of computer rooms as well as a wider acceptance of the replacement of cadavers. This is another issue requiring investigation.

Since computer-based learning systems offer flexibility, enabling students to choose the place, time, pace and process of learning, the use of computer rooms can also be useful in learning outside the classroom, such as the review of anatomical subject matter required by students in the later stages of the training in the health care area. 
CABRAL, D. E. \& BARBOSA, N. J. M. La opinión de los alumnos sobre la utilización de salas de informática para la enseñanza de la Anatomía. Int. J. Morphol., 23(3):267-270, 2005.

RESUMEN: El objetivo de este trabajo fue conocer la opinión de los alumnos sobre la utilización de salas de informática para la enseñanza de la Anatomía. Para ello, fue utilizado un cuestionario con preguntas objetivas, que fue presentado a los alumnos del curso de Odontología, al final de la disciplina de Anatomía, resultando 76 cuestionarios válidos. Estos alumnos tuvieron, en la disciplina, acceso a una sala equipada con computadores con programas de Anatomía, previamente instalados (sala de informática). El análisis de los cuestionarios mostró que, para la mayoría de los alumnos participantes, el uso de la sala de informática facilita mucho el estudio de la Anatomía, aumenta ostensiblemente el logro de los objetivos de la clase y es muy útil para el estudio de la Anatomía. Sin embargo, la mayoría de los alumnos relató no preferir estudiar utilizando esta herramienta de enseñanza y consideró que la sala de informática no puede sustituir las piezas cadavéricas. El presente estudio concluyó que los alumnos investigados consideran la utilización de salas de informática como un elemento que mejora la enseñanza de la Anatomía, sin embargo, no sustituyen a las piezas cadavéricas.

PALABRAS CLAVE: Anatomía; Educación; Tecnología educacional; Métodos de enseñanza.

\section{REFERENCES}

Azis, M. A.; Mckenzie, J. C.; Wilson, J. S.; Cowie, R. J; Ayeni, S. A. $\&$ Dunn, B.K. The human cadaver in the age of biomedical informatics. Anat. Rec., 269(1):20-32, 2002.

Bridges, D. Transferable skills: a philosophical perspective. Stud. High. Educ., 18 (1):43-51, 1993.

Cassady, J. C. Student and instructor perceptions of the efficacy of computer-aided lectures in undergraduate university courses. $J$. Educ. Comput. Res., 19:175-89, 1998.

Ellis, H. Teaching in the dissection room. Clin. Anat., 14:149-51, 2001.

Evans, C.; Gibbons, N. J.; Shah, K. \& Griffin, D. K. Virtual learning in the biological sciences: pitfalls of simply putting notes on the web. Comput. Educ., 43:49-61, 2004.

Filler, T. J.; Jerosch, J. \& Peuker, E.T. Live interdisciplinary teaching via the internet. Comput. Methods Programs Biomed., 61:157$62,2000$.

Hariri, S.; Rawn, C.; Srivastana, S.; Youngblood, P. \& Ladd, A. Evaluation of a surgical simulator for learning clinical anatomy. Med. Educ., 38(8):896-902, 2004.

Jones, D. J. Reassessing the importance of dissection: a critique and elaboration. Clin. Anat., 10:123-7, 1997.

Kallinowski, F.; Mehrabi, A.; Gluckstein, C.; Benner, A.; Lindger, M. \& Hashemi, B et al. Computer based training: a new method in surgical education and continuing education. Chirurg., 68:4338, 1997.

Kirkpatrick, H. \&Cuban, L. Should we be worried? What the research says about gender differences in access, use, attitudes and achievement with computers. Educ. Technol., 38(4):56-61, 1998.

Kulik, C. C.; Kulik, J. A. \& Schwalb, The effectiveness of computerbased adult education: a meta-analysis. J. Educ. Comput. Res, 2:235-252, 1986.
Kulik, J. A.; Bangert, R. L. \& Williams, G.W. Effects of computerbased teaching on secondary school students. J. Educ. Psychol., 75:19-26, 1983.

McLaghlan, J. C.; Bligh, J.; Bradley, P. \& Searle, J. Teaching anatomy without cadavers. Med. Educ., 38:418-24, 2004.

Najjar, L. Multimedia information and learning. J. Educ. Multimedia Hypermedia, 5:129-50, 1996.

Perry, T. \& Perry, L. A. University students' attitudes toward multimedia presentations. Br. J. Educ. Technol., 29:375-7, 1998.

Salomon, G. \& Perkins, D. N. Rocky roads to transfer: rethinking mechanisms of a neglected phenomenon. Educ. Psychol., 24(2):113-42, 1989.

Van Braak, J. P. Domains and determinants of university students' self-perceived computer competence. Comput. Educ., 43:299312,2004

Waugh, R. A.; Mayer, J.W.; Ewy, G.A; Felner J. M; Issenberg B.S; Gessner I.H; Rich S; Sajid A.W. \& Safford R.E. Multimedia computer-assisted instruction in cardiology. Arch. Int. Med., 155(2):197-203, 1995.

Whitley, B.E. Gender differences in computer-related attitudes and behavior: A meta-analysis. Comput. Hum. Behav., 13(1):1-22, 1997.

Correspondence to:

Dr. Etenildo Dantas Cabral

Department of Anatomy

Universidade Federal de Pernambuco

CEP: $50740-530$

Recife - $P$ E

BRAZIL

Email:etenildo@rce.neoline.com.6r 